\title{
A STUDY ON THE EFFECTIVENESS OF MAJOR PROMOTIONAL ACTIVITIES IN DIGITAL MARKETING_WITH SPECIAL REFERENCE TO HIMALAYA PRODUCTS
}

\begin{tabular}{|c|c|}
\hline Supreeth.D & P.Archana \\
RNSIT COLLEGE, BANGALORE-98 & Assistant Professor, RNSIT COLLEGE, \\
& BANGALORE-98 \\
\hline
\end{tabular}

\section{Introduction:}

Digital marketing involves promoting products and services using various digital channels to reach consumers at the right time through their preferred channel. Digital channels are rendered and accessed via desktops, tablets, mobile, smart phones and gaming consoles and can effectively deliver personalized content and promotions. With the increased use of the web, social media, and mobility, organizations are leveraging digital channels for wider and more effective customer reach, by launching multiple global and region-specific campaigns. This digital adoption helps provide costeffective, consistent personalized customer messaging as compared to traditional marketing such as print, television, direct mail and so on.

Organizations are leveraging digital marketing methods for successful marketing strategy implementation inbound marketing through publishing content online in the form of portals, podcasts, e-journals, online campaigns, social media marketing, search services; and outbound marketing including email marketing, RSS (Really Simple Syndication) feeds and others

\section{OBJECTIVES OF THE STUDY:}

The objectives of the study are mentioned below.

- To explore the most used digital media by the target group.

- To examine the effectiveness of the major promotional activities in digital media

- To identify the most effective digital marketing strategies to the company

\section{METHODOLOGY:}

\section{COLLECTION OF DATA}

The data was collected from two different sources

\section{PRIMARY DATA}

The primary data has been collected with the help of a questionnaire, prepared specially for the agents, retailers and consumers to be administered for their responses

- Questionnaire

- Direct Interview.

\section{SECONDARY DATA}

Secondary data is what the researcher collects from different sources. It also helps to get elaborated information to do the research. 
Secondary data has been collected from

- Books

- Magazines

- Internet

- Newspapers

- Past Records and Files

- Journals.

\section{LITERATURE REVIEW}

\section{Organizing today for the Digital Marketing of Tomorrow:}

The rapid development of new interactive media such as on-line services and the World Wide Web has taken most consumer marketers by surprise. Many are struggling to "guesstimate" the likely impact of interactive media on consumer marketing, wondering what they should do and how they should go about doing it. Those who move forward do so with mixed success. Our recent analysis of nearly a hundred web sites of Fortune 500 consumer marketing companies shows that most of today's interactive media marketing applications are uninspiring and, we would argue, fall far short of the potential of interactive media. Yet there is emerging evidence that new media represent both a tremendous MICHAEL ZEISSER is a Principal at opportunity and a serious threat for marketers today. McKinsey \& Company, New York. To address this apparent gap, we have developed an integrated perspective on leveraging interactive media for marketing, which we refer to as digital marketing. Our perspective on digital marketing is articulated around four key issues: for whom does digital marketing represent an important opportunity, what elements should be included in the digital marketing program, and how should the digital marketing organization be designed?

By, Andrew Parsons, Michael Zeisser and Robert Waitman, 1998

\section{Global Marketing for the Digital Age}

Packed with innovative ideas, entertaining examples and unique research, this landmark book shows that how to develop a global marketing program that uses digital technology to its fullest potential.

By Bill Bishop, published on February 1999 by NTC Publishing Group

\section{Digimarketing : The Essential guide to New Media \& Digital Marketing}

New media has rapidly bought the power of anyone to create and share context with everyone. But this is only part of a much bigger sea change brought about by digital technology. Massive social networks are being digital watering holes that connect people globally. Virtual worlds such as second life are attracting millions of users to parallel, digital met verses.

By Kent Wertime and Ian Fenwick, 2008

\section{ANALYSIS AND INTERPRETATION}

The products of Himalaya used by respondents 
Asia Pacific Journals

\begin{tabular}{|l|l|l|}
\hline Option & No Of Respondents & Percentage (\%) \\
\hline Face Care Products & 62 & $62 \%$ \\
\hline Body Care Products & 20 & $20 \%$ \\
\hline Oral Care Products & 8 & $8 \%$ \\
\hline Hair Care Products & 10 & $10 \%$ \\
\hline Total & 100 & $100 \%$ \\
\hline
\end{tabular}

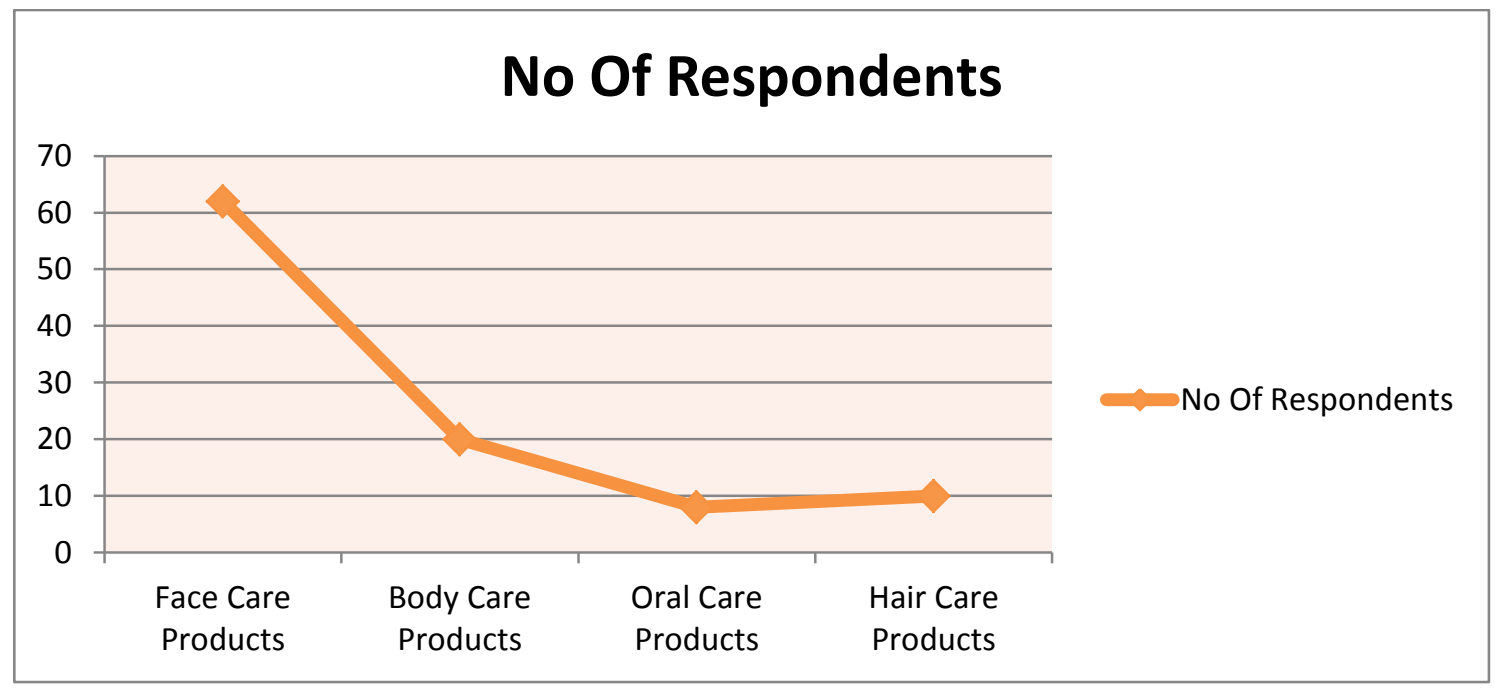

Interpretation: Majority of the respondents use face care products

Channel through which respondents got to know about Himalaya products

\begin{tabular}{|l|l|l|}
\hline Option & No Of Respondents & Percentage (\%) \\
\hline Print & 2 & $2 \%$ \\
\hline Digital & 17 & $17 \%$ \\
\hline Television & 59 & $59 \%$ \\
\hline Family \& Friends & 20 & $20 \%$ \\
\hline Others & 2 & $2 \%$ \\
\hline Total & 100 & $100 \%$ \\
\hline
\end{tabular}




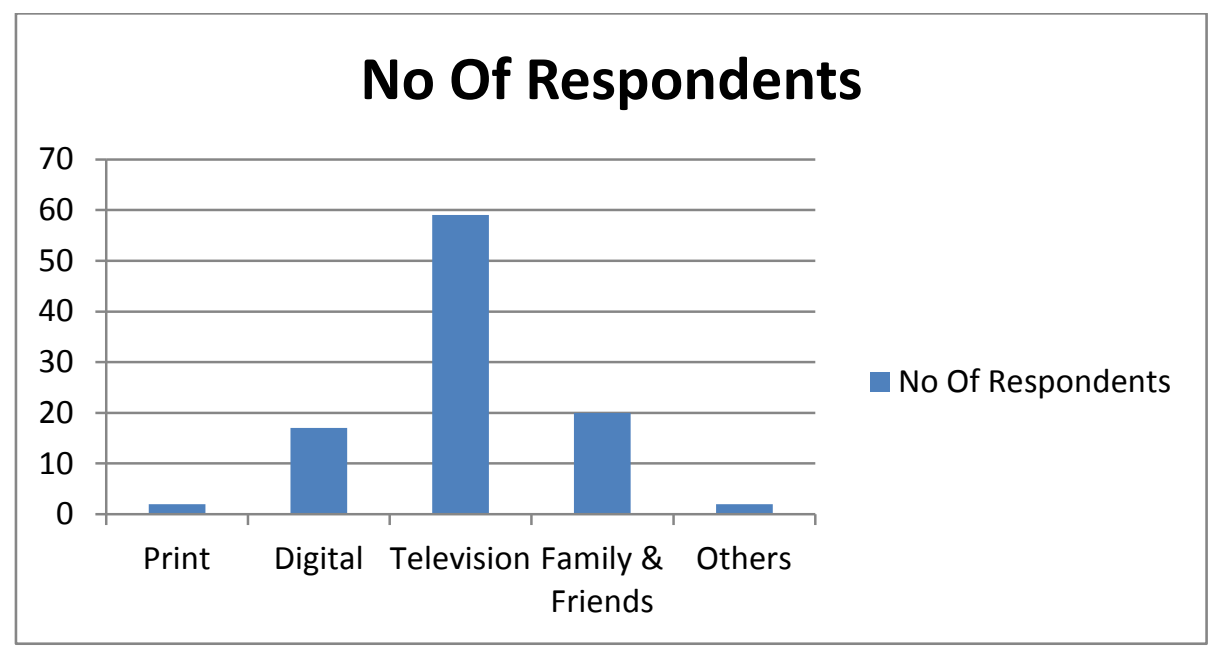

Interpretation: Majority of the respondents got to know about the Himalaya products through television ads

The rating given by respondents according to the usage of devices

\begin{tabular}{|l|l|l|}
\hline Rating & No Of Respondents & Percentage $(\%)$ \\
\hline 1 & 8 & $8 \%$ \\
\hline 2 & 2 & $2 \%$ \\
\hline 3 & 12 & $12 \%$ \\
\hline 4 & 18 & $18 \%$ \\
\hline 5 & 60 & $60 \%$ \\
\hline Total & 100 & $100 \%$ \\
\hline
\end{tabular}

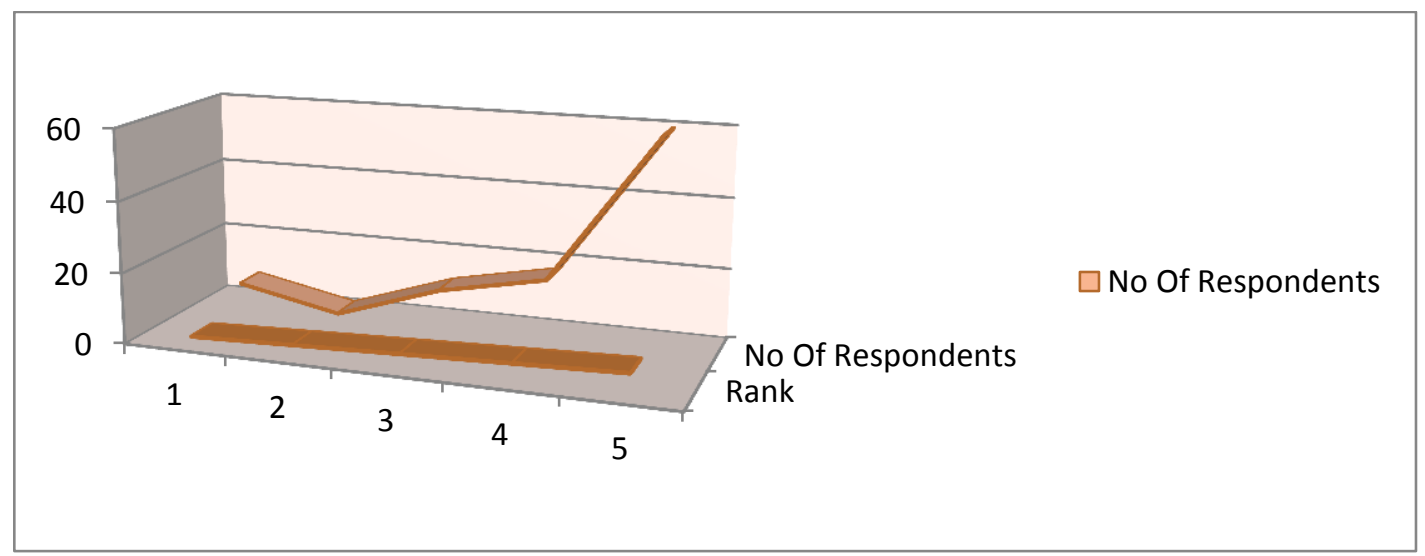

$60 \%$ of the respondents rated the usage of smart phones as 5 , which means that smart phone is used more by respondents. 


\section{FINDINGS}

- Smart phones are the most used devices

- Social media is the most used digital media in a day

- Very less people have watched Promotional activity of Himalaya Products in digital media

- The most effective promotional activities in digital marketing are in the following order,

1. Search Engine Optimization

2. Social media marketing

3. Pop-up ads

4. Email marketing

5. Content Marketing

6. Banner ads

- Facebook is the top ranked social media by the respondents.

- Majority of the respondents agree that the buying decision of beauty product is influenced by the promotional activities in Digital Marketing.

- Majority of the respondents agree that the preference towards the Himalaya Products may be influenced the promotional activities in Digital Marketing.

\section{CONCLUSION}

Based on the findings gathered from the above research, we can conclude that,

- Social media is the most used digital media

- The promotional activities in digital marketing is positively correlated with the buying decision of respondents, hence the company can implement Digital Marketing.

- The following promotional activities in digital marketing are the most effective, 1. Search Engine Optimization

2. Social media marketing

3. Pop-up ads in the internet.

\section{REFERENCES}

[1] Fisher. E. Donald and Jordan. J. Ronald (2006), Security Analysis and Portfolio Management, Pearson Prentice Hall.

[2] http://www.bseindia.com/markets/e quity/EQReports/StockPrcHistori.a spx?flag $=0 \&$ expandable $=7$

[3] http://www.rbi.org.in/scripts/BS_V iewBulletin.aspx? $\mathrm{Id}=15232$

[4] Kevin. S (2008), Portfolio Management, $2^{\text {rd }}$ edition, PHI Learning Pvt. Ltd, New Delhi. 